\title{
Management of Social and Economic Security of the Region
}

\author{
Khairullov D.S. \\ Saipullaev U.A.
}

a b Kazan Federal University, Kazan, 420008, Russia

Doi:10.5901/mjss.2014.v5n12p177

\begin{abstract}
The article defines the concept of socio-economic security of the region, the problems of social and economic security of the region in terms of Russia's entry into the World Trade Organization (WTO), necessary conditions for its ensuring. The main directions of modern regional economic policy, that meet the goals of ensuring socio-economic security of the region, are developed. Government regulation tools are recommended.
\end{abstract}

Keywords: region, problems of socio-economic security of the region in terms of Russia's accession to the WTO, the terms of the socio - economic security of the region, regional economic policy, management of social and economic security of the region.

\section{Introduction}

In modern conditions of socio-economic transformation of the Russian Federation, searching of forms and methods of socio-economic security of the region is becoming an urgent task of ensuring independence of national economy, its stability and resilience, the ability to continuously update and improve. An important condition for sustainable development of regional economy is to give the subjects of the Russian Federation independence in the management of financial, industrial and natural resources, conducting of foreign economic activity. This allows ensuring the maximum development of its own economic base in each subject of the Russian Federation, promoting the socio-economic security of the region.

Socio-economic security of the region depends on the level of self-sufficiency and self-financing of the region, the development of its economic potential (industrial, labor, natural, investment, innovative, scientific). Socio-economic security of the region is determined by the stability of regional economic systems' functioning (nucleating production, territorial-economic complex of the region as a whole). Achievement of socio-economic security of the region involves internal and external stability of the regional system. The internal stability is understood as the sustainable development of regional nucleating production, a stable surplus of goods' export - import, employment and adequate standard of living of the population. The external stability is understood as the stability of regional payment balance, a stable trade surplus, stabilization fund (gold reserves), the effectiveness of the federal equitable regional intergovernmental fiscal relations, the region's place in the Russian and global division of labor.

In modern conditions of Russia's accession to the World Trade Organization (WTO) the problems of ensuring internal and external stability of the regional system is emerging. Depending on the structure of the regional system, the problems of socio-economic security of the region will have their regional characteristics. Solving the problems of socioeconomic security of the region requires new approaches in determining the regional economic policy, the development of effective tools, forms and methods of management of social and economic security of the region.

\section{Problem Formulation}

Definition of the concept and essence of socio-economic security of the region, conditions and regional peculiarities of its security. An explanation of the problem of ensuring socio-economic region's security in the conditions of Russia's entry into WTO.

\section{Method}

The methodological basis of the research is a systematic approach, which allowed to fully study the research problem. In 
the course of this investigation the general scientific and special methods of research: methods of dialectics, a systematic method of analysis of economic processes, logical, comparative and statistical analysis. These methods were used in various combinations at various stages of study, depending on the goals and tasks.

\section{The Results}

The sustainable development of the regional economy of a particular region along with the general laws of national economic development, has unique characteristics which are defined by the structure of GRP, a specific gravity of competitive products of basic industries in the total volume of the regional production, the presence of export sector in the economy of the region, security resource potential (including scientific), incomes of the population, etc.

Socio-economic security of the region is determined by the stability of functioning of structure-forming production. The economic stability of the entity is the ability of the economy to resist and prevent exposure that could lead to the decline in production. The production, which ensures the release of necessary commodities with minimal costs with efficient using of factors of production and in time, can be steadily developing. Territorial and economic sustainability of the economic complex of the region is determined by its ability to maintain a continuous expanded reproduction, which is ensuring the stabile increase of a given level of output production and economic indicators.

The stability of reproduction of the territorial-economic complex of Tatarstan Republic is determined by the level of industrial

development.

The GRP structure of Tatarstan has its regional peculiarities - the highest proportion of economic activities has its regional particular qualities: the greatest proportion of it contains mining (22.9\%), manufacturing production (15.4\%), wholesale and retail trade (13.5\%).

In the GRP structure there is the annual growth of transport and communication: its share increased from $7.3 \%$ in 2005, $8 \%$ - in 2008 to $8.2 \%$ - in 2011. (Fig. 1)

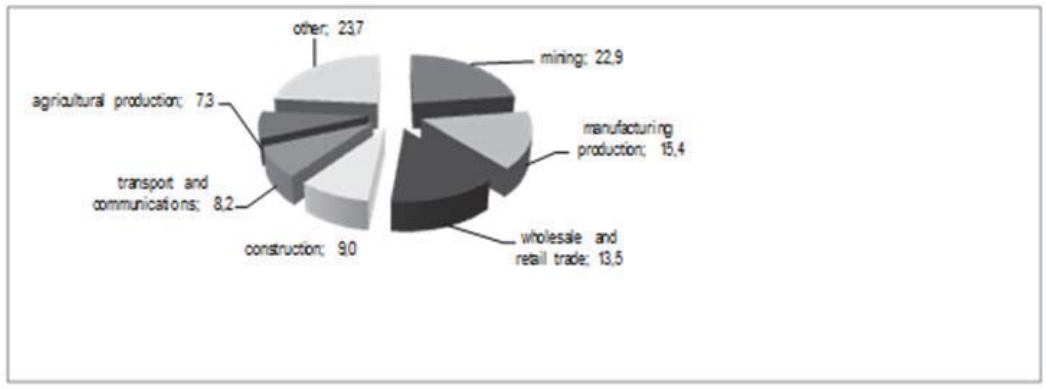

Figure 1. GRP structure by the types of economic activity in the Republic of Tatarstan in 2011. [14] (at current basic prices, as a percentage of total)

Annual dynamics of the Republic of Tatarstan GRP is characterized by increasing index, but during the financial and economic crisis, the growth rate of GRP slowed (The decline due to the global financial crisis is observed in 2009), in 2010 this reduction was restored. Overall, between 2006 and 2010. GRP growth rates of the republic exceeded growth of GRP in the Russian Federation. This trend has continued in subsequent years.

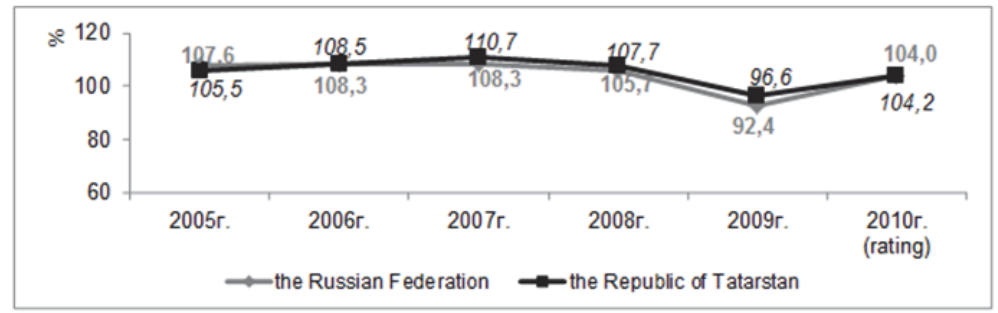

Figure 2 : Volume indexes of GRP of the Russian Federation and the Republic of Tatarstan in 2005 and 2010. 
[10] (percentage to the previous year)

The greatest contribution to the change in economic growth in 2010 provided such activities as: manufacturing (2.8 $\%)$, real estate, renting and business services (1.6\%), wholesale and retail trade (1.2\%), transport and communications $(0.5 \%)[10]$.

There has been significant growth in the volume of industrial products (1294.5 billion rubles in 2011 , or $138.7 \%$ compared to 2008), agricultural production (165.6 billion rubles in 2011 or $152.6 \%$ in comparable prices to the level of 2010), the level of investment demand (was attracted 356.7 billion rubles of investment in 2011), the expansion of construction, a marked increase in profits in the real sector, the size of living wage and the minimum consumer budget. [11] In general, the growth rate of the main indicators of socio-economic development of Tatarstan Republic is higher than in the Russian Federation (Table 1).

Table 1: Comparative indicators of the socio - economic development Republic of Tatarstan and the the Russian Federation [15]

\begin{tabular}{|c|c|c|c|c|}
\hline \multirow[t]{2}{*}{ Indicators } & \multicolumn{2}{|c|}{$\begin{array}{l}\text { the Russian } \\
\text { Federation }\end{array}$} & \multicolumn{2}{|c|}{$\begin{array}{l}\text { Republic of } \\
\text { Tatarstan }\end{array}$} \\
\hline & 2010 & 2011 & 2010 & 2011 \\
\hline $\begin{array}{l}\text { 1. Gross domestic product (GDP) / Gross Regional Product (GRP) in comparable } \\
\text { prices,\% to previous year }\end{array}$ & 104,3 & $104,3^{*}$ & 104,2 & $104,6^{*}$ \\
\hline 2. The Consumer Price Index,\% to December of the previous year & 108,8 & 106,1 & 108,2 & 105,9 \\
\hline 3. The index of the industrial production, in $\%$ to the previous year & 108,2 & 104,7 & 108,7 & 105,7 \\
\hline $\begin{array}{l}\text { 4. The volume of agricultural production of all agricultural producers, in comparable } \\
\text { prices, } \% \text { to previous year }\end{array}$ & 106,0 & $106,2^{*}$ & 113,6 & $107,8^{\star}$ \\
\hline $\begin{array}{l}\text { 5. The volume of investments (fixed capital) on the territory of all sources of funding, in } \\
\text { comparable prices, } \% \text { to previous year }\end{array}$ & 106,0 & $106,2^{*}$ & 113,6 & 107,8 \\
\hline $\begin{array}{l}\text { 6. The volume of work performed by the activity "Construction", in comparable prices, } \\
\text { in\% to the previous year }\end{array}$ & 103,5 & 105,1 & 104,9 & 106,8 \\
\hline $\begin{array}{l}\text { 7. Commissioning residential houses at the expense of all sources of funding, in } \% \text { to the } \\
\text { previous year }\end{array}$ & 97,6 & 106,6 & 100,8 & 118,2 \\
\hline 8. Turnover of the retail trade at constant prices, $\%$ to previous year & 106,3 & 107,2 & 108,9 & 109,1 \\
\hline 9. $\quad$ Real accrued wages, in $\%$ to the previous year & 105,2 & $103,5^{*}$ & 107,1 & 107,5 \\
\hline $\begin{array}{l}\text { 10. The average monthly accrued salary of an average for the year, in } \% \text { to the previous } \\
\text { year }\end{array}$ & 112,4 & $112,2^{*}$ & 113,3 & 116,1 \\
\hline 11. Cash income per capita, in\% to the previous year & 111,0 & 109,7 & 114,1 & 109,2 \\
\hline
\end{tabular}

Thus, the region's ability to withstand to the various impacts (crises, social instability, etc.) and a rapid return to the original state in case of nonobservance, or achieving a higher point in its development shows a sufficient level of socioeconomic security of the region.

In general, social and economic security of the region depends on the level of self-sufficiency and self-financing of the region.

The level of self-sufficiency of the region, means its security of production, labor and natural resources, development of science, innovation and investment potential, the presence of structure-competitive industries, the products of which has a dominant position in the economy of the country. Appropriate level of self-sufficiency in the region allows it to pursue an independent economic directed on ensuring the sustainable development of the regional economy Trade balance of export-import of goods in the region, including the foreign trade balance should be steadily positive.

The stability of self-financing of regional economy is provided by conducting financial, credit, tax and price policies, development of securities market as a source of capital flow into the regional branches of the economy, the establishment of equal relations in the economic field between the federal center and the regions, the development of effective tools of the state regulation of investment and innovation activities, the increase in volumes of competitive export production, increasing per capita income.

Self-sufficiency of the region is realized through obtaining income from commercial activities of business entities. Businesses and organizations objectively unite into the interconnected managing complex to provide extended reproduction process on the basis of costs' self-supporting and maximizing profits.

Sustainable development of the regional economy is determined by the following conditions: 
1. Economic independence;

2. A stable and sustainable development of the regional economy;

3. Maintaining the continuous growth of the regional economy;

4. Increasing of the life quality.

Thus, the sustainable development of the regional economy consists of four essential elements:

- economic independence of the region expresses the degree of its economic security (primarily financial) resources that allows to conduct the independent economic policy, the development of management forms and methods for socio- economic security of the region;

- stable and sustainable development of the regional economy is the ability of the region's economy to withstand to the various impacts, leading to its decline and a rapid return to the original state in case of nonobservance, or to achieve higher point in its development, steady improvement in the quality of life and ensure a constant expanded reproduction of territorial and economic complex and providing of the life quality;

- maintaining the continuous growth of the regional economy is based on scientific and technological progress, innovation progressive forms and methods of work organization, the development of effective tools and methods for regulation of investment and innovation, ensuring safe living standards in the region;

- maintaining and increasing the quality of life is achieved through the development of state development programs, where is the key indicator is achievement of criteria of the life quality.

The absence of one of these conditions is becoming a problem in ensuring socio-economic security of the region. system.

Achieving socio-economic security of the region imply ensuring internal and external stability of the regional

Internal sustainability implies sustainable development of the structure-forming industries, maintaining a stable positive balance of export-import of products, providing employment and the appropriate level of the population's life.

External sustainability implies the stability of the balance of payments of the region, stable the foreign trade balance, the presence of the stabilization Fund (gold reserve), the effectiveness of equal Federal-regional inter-budgetary relations, region's place in the all-Russian division of labour.

Thus, in our opinion, the concept of socio-economic security of the region means the region's ability to resist negative influences of various character (such as crises, social instability, etc.), that lead to the infringement of internal and external stability of the regional system, quickly return to its original state in case of its violation, or achieve a higher point of its development, steady increase in the quality of life of the population and to ensure expanded reproduction of territorial-economic complex.

A special approach for solving problems of socio - economic security of the region, related to the structure of the regional economy, is required. Abolition the old industrial structures of management of regional enterprises during the market reforms, requires from the authorities searching for new forms and methods of cooperation in a structure of the regional economy. Formation of the large inter-branch complexes for competitive output on the basis of such cooperation promotes the increasing of socio-economic security of the region, which is particularly important in the context of Russia's accession to the (WTO). Such cross-industry complexes can reduce unemployment of the population by providing new jobs and increase the income of territorial budgets through tax deductions from profits earned from the sale of the products of these enterprises in the domestic and foreign markets. That will contribute, in general, to improving the socioeconomic security in the region.

Thus, the regional authorities during the development of regional economic policy should include measures of state support for the development of basic sectors of the economy, which are affecting the socio-economic security of the region.

Former paradigm of sustainability built on the principles of ensuring local stability by achieving global sustainability of macro systems. It meant that the stability of the region's economy in the recent past was conditioned entirely by the role it performed in the system of territorial division of labor, and thus was the derivative from the stability of the entire economy of the country, but the crisis of recent years is most evident in highly specialized areas of industry.

Relatively prosperous were the regions with a diversified economy, they were better adapted to the new conditions. It leads to two fundamentally important conclusions - questions:

How to achieve stability in the new conditions? As before? Or on the contrary, should it be based on the movement from sustainability at local level (enterprise, region) to macro-sustainability?

Can the concept of sustainable development of the region in the present conditions of Russia's accession to the WTO be based, as before, on the increasing specialization of the regional economy, or should it focus on a diversified 
model of competitive territorial-economic complex?

Answers to these questions are very important for the development of the modern concept of sustainable development in the region.

In general, there are following problems of socio-economic security of the region, emerging in modern conditions of Russia's joining the WTO:

1. Not specific separation of responsibilities in the economic field between the federal center and the regions, especially in the financial relations with the federal budget;

2. Non-diversified economic structure of the region, which is an important issue in terms of Russia's accession to the WTO;

3. Necessity of economic restructuring in the region, which is adequate to the requirements of the WTO market and aimed at developing competitive basic industries that enhance the stability and security of social and economic development of the region;

4. Searching of sources of investment for economic restructuring of the region;

5. The lack of competitiveness of regional production, the displacement of domestic producers from domestic market as a result of foreign products import that will increase as a result of Russia's accession to the WTO;

6. Underdevelopment of the intellectual property market;

7. Lack of securities market as a source of capital mobility in the regional industry;

8. The threat of food security due to imports of cheaper goods from abroad;

9. Lack of clearly developed system of quantitative target indicators of socio-economic security of the region based on a modern, scientifically based concept of sustainable regional development;

10. Low efficiency of the public administration system of socio-economic security of the region [8].

11. Solving these problems requires new approaches in determining the regional economic policy, the development of effective systems, tools and methods of state regulation of the socio-economic security of the region.

12. The priorities of the regional economic policy at this stage should be:

13. The implementation of institutional reforms that promote coordination of activities of public institutions to ensure socio-economic security of the region;

14. Formation of the effective system of control of socio-economic security in the region;

15. Development of government measures for supporting the development of high-tech and competitive basic industries and economic sectors. These measures will promote to increasing social and economic security of the region;

16. The restructuring of organizational structure of the regional economy's management in line with the challenges faced in the implementation of industrial, social, investment and science - technology policy to ensure the safety and sustainability of the regional economy in the conditions of WTO market;

17. Creating a favorable investment climate, providing inflow of foreign investment;

18. Active social policy aimed at reducing property differentiation in the region;

19. Promotion the development of investment activity in the region;

20. Development of a regional securities market;

21. Increasing the life quality of population;

22. Effectuation of restructuring of economy to the requirements of WTO market that enhances the production of competitive products.

23. Development of foreign trade activities with near/far-abroad countries;

24. 12 Providing more efficient use of resources in the region;

25. Organization of the staff training in modern methods of analysis of business enterprise and managerial decision-making on sustainable development of economic entities.

Effective instruments of government socio-economic security of the region in modern conditions are forecasting and programming. No less important in this case is evaluation of economic potential of the region, which is the starting point for the formation of the concept of science-based sustainable and safe development of the region [8].

Determining role in the development of the sustainable socio-economic program of the region plays forecasting. It covers various sectors of life in the region: demographics, resource potential, including natural resources, consumer demand, the dynamics of the production, the results of introduction of innovations into the economy and so on. Consolidated economic outlook completes the predictive work. It characterizes summarized macroeconomic situation in the region, the rate and the basic proportions of economic development.

The problem is not to give a simple statement of a future development, but to focus selection on the sustainable 
and secure socio - economic development of the region.

For this purpose it is necessary to formulate a comprehensive model of the reproductive process of the regional economy and on its basis to determine the system of basic parameters of sustainable socio-economic development of the region as a whole to ensure socio-economic security and to develop the tools of government regulation.

\section{Conclusions}

In modern conditions of Russia's accession to the WTO the actual task for the region is to ensure the sustainable development of the regional economy.

The regions of Russia, being in common economic space of the country play an important role in the processes of ensuring the security and stability of the national economy.

Therefore, the determining factor of security and stability of the national economy in terms of Russia's accession to the WTO becomes an ensuring of socio-economic security of the region.

Socio-economic security of the region depends on the level of self-sufficiency and self-financing of the region, the development of its economic potential (industrial, labor, natural, investment, innovative, scientific).

Socio-economic security of the region is also determined by the stability of regional economic systems functioning. (nucleating production, territorial-economic complex of the region as a whole).

Ensuring socio-economic security of the region in terms of Russia's accession to the WTO requires new approaches in regional economic development policy to meet the challenges of social and economic security of the region, searching for new tools, forms and methods of socio- economic security of the region.

\section{References}

Sarkin, A.V., Bagautdinova, N.G., Averianov, B.A. Development and implementation of adaptive science-intensive manufacture management system based on management processes automation // World Applied Sciences Journal, 27(13), 2013, $159-164$.

Averianov, B.A., Bagautdinova, N.G., Sarkin, A.V. Estimation of manufacturing enterprise development risks in process of operational activity // World Applied Sciences Journal, 27(13), 2013, 202-206.

Safiullin, M.R., Elshin, L.A., Prygunova, M.I., Galyavov, A.A. (2013). Complex Analysis of Prospects of the Volga Federal District Regions Development: Methodology and Practice. World Applied Sciences Journal 27, 4, 508-511.

Askhatova L.I., Bulnina I.S. Quality-of-life (QOL) improvement as a strategic resource of sustainable social and economic development of a region. Life Science Journal $2014 ; 11(6 s): 354-357$.

Bulnina I.S. International legal standards of the bar activity and its domestic security (using the example of the Russian Federation and France. Life Science Journal 2014; 11(6s): $469-472$.

Panasyuk, M.V., Safiullin, L.N., Pryadko, I.A., Anopchenko, T.Y. Classification of large and socially important enterprises of the region by the levels of their economic solvency // World Applied Sciences Journal, 27(13), 2013, 140-144.

Fakhrutdinova, E., Kirshin, I., Kolesnikova, J., Salyakhov, E. The influence of cross-country technological transfer on economic profit formation// Middle East Journal of Scientific Research. Volume 17, Issue 12, 2013, Pages 1632-1634.

Panasyuk, M.V., Bagautdinova, N.G., Safiullin, L.N., Novenkova, A.Z. Territorial approach to solving the region strategic management problems // World Applied Sciences Journal, 27(13), 2013, 149-153.

Shalmuev A.A. Theoretical and methodological basis for sustainable development of the region / / Innovation 2006 - № 3 - p.28- 32

Tatarstanstat. Statistical Yearbook of Kazan, 2012.-521p

Validova A.F. Inflation targeting in developing countries: perspectives for Russia. Life Science Journal 2014; 11(6s): 494 - 498.

Markov, V.A., Bagautdinova, N.G., Yashin, N.S. Improvement of instruments of the state cluster-based policy in the contexts of economic entities interrelation asymmetry // World Applied Sciences Journal, 27(13), 2013, 130-134. 